\title{
Beauplaisir as a Disabled Libertine in Eliza Haywood's Fantomina; or Love in a Maze
}

\author{
Difeng Chueh \\ Assistant Professor, Feng Chia University, Taichung, Taiwan. Email: difeng.c@gmail.com
}

\begin{abstract}
This paper aims to explore Beauplaisir's disabled libertine identity in Eliza Haywood's Fantomina; or Love in a Maze (1725) in order to understand how "disability" was conceptualized by eighteenth-century authors. Beauplaisir is a libertine obsessed with pursuits of sexual pleasure with various women. In those sexual adventures, Beauplaisir constructs his abled libertine identity through his observation skills. In fact, Beauplaisir's observation skills also render him disabled. Haywood's portrayal of Beauplaisir's disabled libertine identity offers another way to examine meanings of disability in eighteenth-century literary works. As I will contend, the definition of "disability" was not limited to a person's physical or mental impairment in the eighteenth century. Instead, an eighteenth-century person could become disabled when s/he lost certain qualifications for becoming a member of a particular group. The word "disabled" or "disability" was used in this way by eighteenth-century writers such as Samuel Johnson and Jonathan Swift. As I will show, Beauplaisir's disabled libertine identity is a result of his being excluded from the abled libertine group. This exclusion results from a trick imposed on him by Fantomina. Thus, examinations of Beauplaisir's disabled libertine identity will point out another side of "disability."
\end{abstract}

Keywords: disabled libertine, eighteenth-century libertinism, eighteenth-century disability studies, exclusion

\section{Introduction}

When it comes to representations of femininity and masculinity in Eliza Haywood's Fantomina; or Love in a Maze (1725), most studies emphasize how Fantomina, the eponymous character of the novel, displays her sexual desire. For example, in "Performing the Passion in Eliza Haywood's Fantomina and Miss Besty Thoughtless," Emily Hodgson Anderson examines how Fantomina keeps her reputation, while freely expressing her sexual desire with Beauplaisir by means of masquerade. In the article, Anderson argues that "Fantomina's continued masquerade prevents the typical consequences of seduction - the abandonment and scandal that would forestall any future performance - and prolongs her powers of expression. The sincerity of her desire for Beauplaisir is reasserted with each performance" (Anderson, 2005, 4). Similar to Anderson, Helen Thompson also considers that Fantomina adopts masquerade as a way to carry out her insatiable sexual pursuit of Beauplaisir in "Plotting Materialism: W. Charleton's The Ephesian Marton, E. Haywood's Fantomina and Feminine Consistency." If both Thompson and Anderson focus on Fantomina's strategy of masquerade and similarly argue that Fantomian overpowers Beauplaisir throughout the novel, Tiffany Potter, in "The Language of Feminised Sexuality" arrives at a similar conclusion by exploring how Fantomina manipulates her language to belie that fact that she is the person in control in the

(c) AesthetixMS 2021. This Open Access article is published under a Creative Commons Attribution Non-Commercial 4.0 International License (http://creativecommons.org/licenses/by-nc/4.o/), which permits non-commercial re-use, distribution, and reproduction in any medium, provided the original work is properly cited. For citation use the DOI. For commercial re-use, please contact editor@rupkatha.com. 
relationship with Beauplaisir. In that paper, Potter points out that by “relocating Fantomina's appropriation of the masculinised linguistic realm of seduction into the servant girl's form, Fantomina can reinscribe her own physical virginity at will as she controls Beauplaisir's knowledge and action through her ability to interpret the signs that he assumes are read by men alone" (Potter, 2003, 180).

The results of these studies are important in two ways. First of all, Anderson, Thompson and Potter argue in the same vein to illustrate how Fantomina dominates in her relationship with Beauplaisir and how this dominance is the evidence to the reversal of the traditional seduction plot in which women are all the time victims. In other words, Haywood's Fantomina contributes to the eighteenth-century literary landscape by presenting an alternative to the traditional maledominated relationship. The second importance of these studies is related to what is missing in them. In fact, portrayals of Beauplaisir's masculinity are equally significant in comparison to those of Fantomina's sexual liberation given that Haywood's characterization of Beauplaisir can enrich our understandings regarding the development of eighteenth-century masculinity discourse by demonstrating another way to understand the word "disability" in the eighteenth century.

In the following, I will contend that Beauplaisir becomes a disabled libertine at the end of the novel by exploring how his powerful libertine status is challenged by Fantomina. As I will demonstrate, Beauplaisir's disability is not connected with his physical or mental impairment, a traditional approach to examine a person's disabled condition. Instead, Beauplaisir becomes disabled for his loss of qualification as an abled libertine and his exclusion from that group in his relationship with Fantomina. This result responds to how the word "disabled" was used in the eighteenth century by Samuel Johnson, Jonathan Swift and other literary figures. This usage, as I will contend, reveals how a person's loss of certain qualification could render him or her disabled in the eighteenth century, a possibility which has been overlooked by the eighteenth-century scholars.

\section{Beauplaisir as a Disabled Libertine}

In the novel, Beauplaisir has completed his sexual pursuits with different female characters such as Fantomina, Celia, Widow Bloomer and Incognita. In this case, Beauplaisir seems to be a dominant and sexually aggressive libertine. In fact, Fantomina's well-designed trick is the main reason to make Beauplaisir a disabled libertine. After discussing what Fantomina's trick is, I will then delve into the recent development of eighteenth-century disability studies with a further intention of understanding how the term "disability" was understood and used in the eighteenth century. In so doing, I will conclude this section by demonstrating in what ways Haywood's characterization of Beauplaisir's disabled libertine masculinity can diversify the current scholarship on eighteenthcentury disability discourse.

Fantomina plans her trick on the basis of her comprehension regarding what Beauplaisir's next step is after the completion of sexual pursuit with her. As Fantomina rightly observes, at the end of each sex-hunting game, Beauplaisir becomes "willing to be at liberty to pursue new Conquests" (Haywood, 2004, 51). ${ }^{\left[{ }^{1]}\right.}$ Beauplaisir's intention is actually no secret to Fantomina, and she considers that "Complaints, Tears, Swooings, and all the Extravagancies which Women make use of in such Cases, have little Prevailance [sic] over a Heart inclin'd to rove" (51). Thus, in order to once more engage Beauplaisir, Fantomina pretends to be another woman to seduce Beauplaisir. To say that Fantomina "disguise[s] herself as another woman" is not accurate, since Fantomina takes on identities of another three women, Celia, Widow Bloomer, and Incognita, in order to repeatedly "hear [Beauplaisir] sigh, to see him languish, to feel the strenuous Pressures of his eager Arms, to 
be compelled, [and] to be sweetly forc'd to what she wished with equal Ardour" (51). In so doing, Fantomina reverses the power relationship by taking a dominant position to initiate the whole sexhunting game, a change which I argue is the reason for Beauplaisir to become disabled.

In order to find out what kind of disabled libertine Beauplaisir is, we need to first of all see what is the main feature of Beauplaisir's libertinism. At the beginning of the novella, Haywood introduces who Fantomina is by saying that she is "A YOUNG Lady of distinguished Birth, Beauty, Wit and Spirit, happened to be in a Box one Night at the Playhouse" (41). While Fantomina "happen[s] to" visit this playhouse, Beauplaisir coincidentally appears at the same place. When Beauplaisir and Fantomina meet in the said playhouse, Beauplaisir

address'd her at first with the usual Salutations of her pretended Profession, as Are you engag'd, Madam? - Will you permit me to wait on you home after the Play? - By Heaven, you are a fine Girl! - How long have you us'd this House? - And such like Questions; but perceiving she had a Turn of Wit, and a genteel Manner in her Raillery, beyond what is frequently to be found among those Wretches, who are for the most part Gentlewomen but by Necessity, few of 'em having had an Education suitable to what they affect to appear, he chang'd the Form of his Conversation, and shew'd her it was not because he understood no better, that he had made us of Expressions so little polite (43, emphasis in original).

This passage is worth quoting at length because it indicates the tricks that Beauplaisir employs in his pursuits of women. Beauplaisir is a keen observer, and his talent in observation is first of all represented by the "usual Salutations" (43) he makes to Fantomina. Beauplaisir's questions are not made out of the blue but are a response to Fantomina's "pretended Profession" (43). ${ }^{[2]}$ If Fantomina's disguise prompts Beauplaisir to court Fantomina with those questions, the wit and manner that Fantomina shows in the follow-up conversation forces Beauplaisir to conduct his sexual pursuit by "chang[ing] the Form of his Conversation" (43) after he "perceives" the differences between Fantomina and other prostitutes. No matter which strategy Beauplaisir opts for, his questions reveal how observant he is, a feature of his libertinism. Since being observant is a main feature of Beauplaisir's libertinism, readers can find that Beauplairsir carries out his other sex adventures in an identical way. In the next sex-hunting game with Celia, whom he meets in a house during his stay at Bath, Beauplaisir "ask'd her, how long she had been at Service? - How many Sweethearts she had? If she had ever been in Love? And many other such Questions, befitting one of the Degree she appear'd to be" (53, emphasis added). Compared with the questions made to Fantomina, those for Celia are also the results of his observation about Celia's physical appearance. As I have mentioned previously, these women are no one else but Fantomina herself. The reason why Fantomina's trick leads to Beauplaisir's disability is because it challenges Beauplaisir's status as an observant libertine. In her discussion about how Beauplaisir is outwitted by Fantomina, Margaret Case Croskery reveals the implication of this challenge by contending that

Beauplaisir masters neither his desires (which "burst out uncontrolled") nor the basic facts of the situation (his country lass is, after all, the same "Fantomina" in whom he believes he has lost sexual interest). [Besides,] the "rapacious" role he plays as "victor" is not as well imagined or creatively controlled as the role of the "victim" who has willed this seduction from start to finish (Croskery, 2000, 83). ${ }^{[3]}$

Beauplaisir is in an inferior status in his relationship with Fantomina, since Fantomina controls the development of the whole affair after their first meeting in the opera house. In this sense, Croskery is definitely correct to contend that the victor-victim binary is not as simple as Beauplaisir takes it to be. The dichotomy of "victor" and "victim" works in a reversed way in the relationship between Beauplaisir and Fantomina because Fantomina takes advantage of Beauplaisir's belief in his 
observation skills. Such a belief blinds Beauplaisir to the fact that he pursues no one other than Fantomina in all the sex adventures. For example, when the couple meets in the playhouse, Beauplaisir "look'd in [Fantomina's] Face, and fancy'd that she very much resembled that Lady whom she really was; but the vast Disparity there appear'd between their Characters, prevented him from entertaining even the most distant Thought that they cou'd be the same" (42-3, emphasis added). In comparison with the questions made to Fantomina and Celia, here the word "appear'd" appears to show how important being observant is to Beauplairsir since he heavily relies on it to make his decisions and how he is fooled by Fantomina due to his strong faith in what he sees. In order to understand how the reversal of power relationship between Beauplaisir and Fantomina leads to the representation of Beauplaisir's disability, I need to first of all introduce the current scholarship on eighteenth-century disability.

The current scholarship on the development of eighteenth-century disability studies has three emphases. The first emphasis is related to how a person's or a literary character's physical impairment leads to his or her peril in life. For example, in William Hay's Deformity: An Essay $(1754)^{[4]}$, readers can find how Hay struggles with his deformity:

When I was a Child, I was drawn like a Cupid, with a Bow and Arrow in my Hands, and A Quiver on my Shoulder: I afterwards thought this an Abuse, which ought to be corrected: and when I sate for my Picture some Years ago, I insisted on being drawn as I am, and that the strong Marks of the Small Pox might appear in my Face, for I did not choose to cover over a Lye. The Painter said, he was never allowed such liberty before; and I advised him, if he hoped to be in Vogue, never to assume it again: for Flatters succeed best in the World; and of all Flatters, Painters are the least liable to be detected by those they flatter. Nor are the Ladies the only Person concerned for their Looks (Hay, 1754, 37, emphasis added).

This passage explains how eighteenth-century people reacted to other people's physical deformity and Hay's aversion to such reaction. As Hay clearly indicates, the feeling of being abused arises in his mind when he realizes that his childhood portraits are nothing but lies, since his physical impairment is intentionally left out. According to the conversation between Hay and the painter, this practice was common in the eighteenth century given that eighteenth-century people extremely cared about how they look, as the last line of the passage indicates. As a result, the painter was "never allowed such liberty" to present any sign of physical deformity in a client's portrait. Hay's experience demonstrates how assiduously eighteenth-century people try not to expose their impairment to the public.

Compared to Hay's autobiographical writing, in "Dr. Johnson, Amelia, and the Discourse of Disability," Lennard J. Davis points out how the noseless Amelia, the eponymous character of Henry Fielding's Amelia (1751), is ridiculed by other young ladies who "have turned their heads aside, unable to support their secret triumph, and burst into a loud laugh in her hearing" (Davis, 200o, 65). The triumph these ladies enjoy comes as a result that Amelia's loss of nose "is also seen as a 'loss of exquisite beauty,' which is the same as 'the loss of fortune, power, glory" (Davis, 2000, 65). If the noseless Amelia is mercilessly derided in the novel, the eighteenth-century literary reviewers also heavily criticized Fielding's Amelia because they believed that "the author should have taken care to have had Amelia's nose so compleatly cured, and set to rights, after its being beat all to pieces, by the help of some eminent surgeon, that not so much as a scar remained, and that she shone forth in all her beauty as much after that accident as before" (qtd in Davis's Dr. Johnson, 6667). Along with Hay's Deformity and other characters' reaction to Amelia's disabled condition, this review demonstrates eighteenth-century people's antipathy against disabled others. 
In fact, people with disability would not only be treated as a target for mockery and laughter but also the one for spectacle. In "In the Bodyshop: Human Exhibition in Early Modern England," Stephen Pender claims that "As reflected in vernacular and ephemeral literature of the sixteenth, seventeenth, and eighteenth centuries, the 'discomfort of Deformite' was acute indeed" (Pender, 2000, 114). Pender later explains what this discomfort is by saying that "Subject to general opprobrium and ridicule, monsters were displayed before the curious for 'pleasure' and profit" (Pender, 2000, 114). According to Pender, deformed people were taken to be "monsters" from the sixteenth to the eighteenth centuries and representations of their monstrosity were pleasurable and profitable to other people. In conclusion, Davis, Hay and Pender clearly reveal how miserable the life could be to a disabled person in the eighteenth century.

If the first research focus pays attention to the misery that people with physical impairment suffered from in the eighteenth century, the second one presents a possibility that a person's physical defect may not necessarily cause distress to the person in question. When examining how Samuel Johnson's contemporaries respond to Johnson's disability, Davis points out in Dr. Johnson that "While his contemporaries clearly note his eccentricities, Johnson is not pathologized. [...] Given the extent of Johnson's multiple disabilities, rather little mention is made of them even by Boswell and his contemporaries. For example, portraits of Johnson edit out his disabilities; only his death mask shows the rather dramatic scars on his neck" (Davis, 1995, 55, 61). Although Davis does not make it clear regarding whether it is Johnson's or others' intention to cover Johnson's physical defects in his portraits, his arguments showcase how Johnson is beloved by his contemporaries and biographer, since the former's disability poses no or minor issues to the latter. ${ }^{\left[{ }^{[}\right]}$

Other than Davis, Robert W. Jones shows how a character's deformity could signify his or her virtue in the eighteenth century. In "Obedient Faces: The Virtue of Deformity in Sarah Scott's Fiction," Jones first of all explains how the eighteenth-century society keeps "the age-old notion that a beautiful countenance discovered a beautiful mind" (Jones, 2000, 281). In the later part of the essay, Jones contends that Sarah Scott challenges this "age-old notion" in her novel Agreeable Ugliness: or, the Triumph of the Graces. Exemplified in the Real Life and Fortunes of a Young Lady of Some Distinction (1754). As Jones observes, "such a lack of visual significance is endorsed by Scott's novel as a means to virtue. The misfortune of ugliness - that it fails to signify - is then balanced by the fact that it appears well suited to the heterosocial world of her public and private life: for this reason the narrator appears to find her own deformity consoling" (Jones, 2000, 288). If Davis's article shows how Johnson's physical disabilities did not render him inferior in his relationships with others, Jones's reading of Scott's Agreeable Ugliness gives evidence to how “ugliness" could become a virtue instead of a vice in the eighteenth century. In this case, both articles demonstrate the other side of deformity in the eighteenth century to modern readers.

The third current research direction is associated with the genealogy and various representations of physical impairment in the eighteenth century. For instance, David M. Turner claims in the introduction to Disability in Eighteenth-Century: Imagining Physical Impairment that "the structure of this book takes the form not of a linear sequential argument, but of a series of case studies that examine the representation of impairment in a variety of cultural milieux" (Turner, 2012, 14). In order to demonstrate differences between different kinds of cultural representations of physical impairment, Turner first of all explores "the language of physical impairment in eighteenth-century England and analyses the relationship between 'defect' and 'monstrosity" (Turner, 2012, 14). As Turner concludes in the first chapter, "In various ways, popular and official descriptive terms cast the disabled body as sympathetic, heroic, impoverished, ugly, laughable, violated, or deceptive" (Turner, 2012, 33). Based on this assumption, Turner examines materials ranging from religious 
doctrines, to medical documents, to letters and autobiographical writings, to legal documents. Results of Turner's examinations respond to the definition he concludes in the first chapter in which readers can find that images of the disabled and meanings of the word "disability" were various in eighteenth-century England. In short, Turner's book is part of a combination of the previous two research trends, since it reveals both the positive and negative sides of physical impairment in the eighteenth century. It, at the same time, also shows how meanings and ideas of disability and other related words change from the early modern period to the eighteenth century.

Similar to Turner's book, The Ideal of Disability in the Eighteenth Century, edited by Chris Mounsey and published in 2014, is a collection which includes three sections: methodological, conceptual and experiential. The ten essays included in this collection present how "disability" was conceptualized in the eighteenth century, lives of the disabled people and literary representations of people with various kinds of deformity. The problem with Turner's and Mounsey's books is that both of them still prioritize a person's physical and/ or mental impairment in their discussion, while other situations are ignored. In the following, I will look into what these "other situations" are and then examine how Haywood's portrayal of Beauplaisir's disability can be an example to support the possibility of these alternative disabled conditions. In order to do this, I will resort to Samuel Johnson's, Jonathan Swift's and David Turner's works to find the clue.

Although the modern scholarship on eighteenth-century disability emphasizes a person's or a character's physical or mental impairment, the connotation of the word "disability" is actually not limited to it. In A Dictionary of the English Language, Samuel Johnson defines "disable" as follows: "1. To deprive of natural force; 2 . To impair; to diminish; 3. To make unactive; 4. To deprive of usefulness or efficacy; 5 . To exclude as wanting proper qualification" (Johnson, 1773, 294). According to Johnson's definitions, if a person becomes "disabled," he or she suffers from physical or mental illness, both of which account for his or her loss of "natural force." As a result, the said person will become "impaired," "inactive," or "useless." Johnson's definitions reveal that portrayals of impairment and their effects were without a doubt crucial to the formation of disability as a concept in the eighteenth century. Nonetheless, the last definition of the word "disable" listed by Johnson seems incompatible with others owing to the fact that its implication is broader than the situation of a person's loss of natural force and the influence accompanied by it. This fifth definition, nevertheless, offers another way to delve into another side of "disability" in the eighteenth century. Simultaneously, it provides us with another perspective to examine Beauplaisir's possible disability, since Haywood's portrayal of Beauplaisir, who is neither physically nor mentally impaired, has a loose connection with the existing eighteenth-century disability research trajectories. In order to understand the implication of Jonson's fifth definition of the word "disabled," we need to refer to an interesting passage in David Turner's Disability in Eighteenth-Century England: Imagining Physical Impairment.

As the title of the book suggests, Turner discusses how a person's physical impairment may lead to his disabled situation. Surprisingly, one of Turner's passages seems to suggest another possible disabled situation. In the first chapter of the book, Turner gives a detailed examination of the possible definitions of the term "disability" and their relation to other relevant words in the eighteenth century. ${ }^{[6]}$ In that particular chapter, Turner lists a definition which is similar to Johnson's fifth definition of the word "disabled" by contending that

for although eighteenth-century dictionaries defined "disability" as "being unable [or] incapable", the usage of the term that drew most attention was that in a "law-sense" as when a "Man is so disabled, as to be made incapable to inherit, or to enjoy a Benefit which otherwise he might have done" such as the impediments to inheritance imposed on people 
convicted of "Treason or felony" and their heirs, or "Disability by Act of Law" whereby foreigners were "disabled" from benefitting by English law (Turner, 2012, 17).

From the second line of the definition, Turner clearly tells his readers that foreigners were disabled in comparison with their British counterparts from the perspective of inheritance or benefit due to their non-British nationalities in the eighteenth century. This situation can also be found in the case of people charged with treason or felony. The people in question are disabled because their behavior or identity is against the law, a situation which possibly has no direct association with their physical or mental impairment. Owing to this, the same groups of people become the best example to support Johnson's fifth definition of the word "disable," since they are "excluded" by the law owing to their lack of certain specific qualification, British nationality for example. In other words, if a person was excluded from a particular group due to his loss of qualification to be considered as a member of that group, he could be regarded as disabled in the eighteenth century. Unlike the traditional definition of the word disability, this "loss of qualification" may have nothing to do with a person's physical or mental impairment. In order to support this argument, we need to look at Johnathan Swift's usage of the word "disability."

In "The Advantage Proposed by Repealing the Sacramental Test, Impartially Considered," written in 1732, Jonathan Swift uses the word "disability" in accordance with Johnson's fifth definition of the word "disable" and Turner's observation about the disabled foreigners and criminals. Speaking of the problems of Test Act, ${ }^{[7]}$ Swift claims that "It is true, indeed, that this Disadvantage which the Dissenters at present lye under, of a Disability to receive Church-Preferments, will be easily remedied by the Repeal of the Test" (Swift, 1741-46, 346-7, emphasis added). In Swift's time, people who wanted to be consider eligible for public employment needed to take communion in the established Church of England. In this way, dissenters, including Presbyterians, Roman Catholics and nonconformists, became "disabled" to take any public office. These dissenters were not physically or mentally impaired, whereas their religious beliefs rendered them disqualified for and then excluded from any public employment, a condition which demonstrates another possible application of the word "disability." All in all, while the discussion of physically-disadvantaged people constitutes part of eighteenth-century disability discourse, people who suffer from no physical or mental impairment could still be considered as disabled and thus an outcast due to their loss or lack of qualification to be taken as a member of a particular group.

In fact, Beauplaisir's disability is related to Jonson's fifth definition and Swift's usage of the word owing to the fact that he is neither physically nor mentally disabled. As I have mentioned in the early part of this section, Beauplaisir is not the winner as he projects himself to be in his relationships with Fantomina and her other disguises. This failure to behave as a dominant libertine is the main cause for Beauplaisir's disability because it symbolizes his loss of qualification to be regarded as an abled libertine and his exclusion from that group. In fact, this feeling of being excluded starts to work before Fantomina's trick is made known to Beauplaisir. It is thus necessary to examine the relationship between Beauplaisir and Incognita, the last identity impersonated by Fantomina, with a further intention of knowing how Haywood portrays Beauplaisir's exclusion from the abled libertine group.

In his previous relationships with Fantomina, Celia and Bloomer, there is no hint of Beauplaisir's suspicion of his dominance in those pursuits of pleasure. Beauplaisir's last sex-hunting game with Incognita is the beginning stage for Beauplaisir to question his authority. From the beginning to the end of this adventure, Beauplaisir is constantly in a passive position and his passivity emerges in his inability to know who Incognita really is and what she really looks like. ${ }^{[8]}$ When Beauplaisir leaves the house where the couple meets, he "resented [and] determin'd never to re-enter it, till she 
should pay the Price of his Company with the Discovery of her Face and Circumstances" (67). Beauplaisir is obsessed with "seeing" Incognita's face for it is part of the observation he needs in order to know what he should do with Incognita, a strategy which renders Beauplaisir abled in the previous sex-hunting games. By choosing not to "re-enter" the house unless Incognita reveals her face and her intention, Beauplaisir gets himself away from a house or a woman with whom he becomes disabled given that his abled libertine masculinity faces challenges. This possibility of being transformed from an abled into a disabled libertine is further supported after Beauplaisir realizes that he is never the predator but a prey in these relationships. In the following, I will move to the last part of the novel to elucidate how Beauplaisir is finally excluded from the abled libertine group and how this exclusion results in the representation of his disability.

When Fantomina's mother becomes aware of Fantomina's folly after her daughter's unexpected delivery of a baby girl, she summons Beauplaisir to their house. After hearing Fantomina call him as "the innocent Cause of [her] Undoing," Beauplaisir cries out "What mean you, Madam? I your Undoing, who never harbour'd the least Design on you in my Life” (70). The reason why Beauplaisir dares to claim his innocence in this accusation is based on what he observes. The woman Beauplaisir sees in front of him at this moment is the one whom he meets nowhere else than the drawing room where he never treats her with "that Freedom she expected he wou'd" (42). In other words, Fantomina bears no resemblance to any woman in his previous pursuits of sexual pleasure to Beauplaisir. Thus, Beauplaisir feels shocked to find out that "he should have been blinded so often by her Artifices" (70, emphasis added). Beauplaisir's feeling of shock is inevitable considering that his abled libertine masculinity is constructed mainly by his skills in observation and being "blinded" by Fantomina's trick means his being deprived of this qualification to become abled. If so, we need to look at how Haywood describes Beauplaisir's exclusion from the libertine group depicted before the story ends

After the meeting with our heroine and her mother, Beauplaisir "took his Leave, full of Cogitations, more confus'd than ever he had known in his whole Life” (71, emphasis added). Beauplaisir's confusion represents his exclusion from a familiar, abled libertine life. This feeling of confusion is similar to that of resentment that Beauplaisir undergoes in the previous relationship with Incognita. In both situations, Beauplaisir's observation skills are not as effective as Beauplaisir presumes them to be. That's why Beauplaisir feels confused or resented in the respective relationships. Since being observant is a key to the construction of Beauplaisir's abled libertine masculinity, Beauplaisir loses his membership as an abled libertine after his observation skills fail him to achieve a result which he commonly enjoys. In the end, Beauplaisir turns to be disabled as a result of being excluded from his understanding of what a successful, abled libertine should be like. This result responds to Johnson's fifth definition of the word "disable" and Swift's usage of the word "disability" owing to the fact that it demonstrates how a physically and mentally healthy man can in fact become disabled. Thus, Haywood's portrayal of Beauplaisir's disability opens up another possible way other than the existing two research directions for the modern scholars to examine the development of eighteenth-century disability discourse.

\section{Conclusion}

Haywood's Fantomina; or Love in a Maze is an amatory fiction which enhances its readers' understanding of the formation of eighteenth-century disability studies by presenting a disabled libertine who is neither physically nor mentally disabled. The current development of eighteenthcentury disability studies clearly indicates that the representation of a man's disability is closely associated with his physical or mental impairment and the problems arising from it. While finding 
these approaches accurate, I argued that there is another possible interpretation of a man's disabled situation, one which is indicated in Johnson's definition of the word "disable," in Swift's use of the word "disability" and in Turner's arguments about how foreigners or criminals can be seen as disabled. This possibility is more concerned about how a man will become disabled as a result of being excluded from a group by losing or lacking certain qualification. Take Haywood's Beauplaisir as an example. Beauplaisir is a disabled libertine since he loses the qualification to call himself an abled libertine. This qualification is mostly connected with his observation skills. After finding out that his seeming success in sexually enjoying all the women is a result of Fantomina's trick, Beauplaisir feels confused and lost, a situation which is explicitly represented at the end of the novel. His feeling of confusion symbolizes his exclusion from being called as an abled libertine given that he can no longer believe what he sees. When Beauplaisir realizes this, he loses the power to construct his abled libertine masculinity and thus becomes disabled.

\section{Notes}

${ }^{[1]}$ All the subsequent page references will be keyed to this Broadview edition.

${ }^{[2]}$ In this meeting, Fantomina disguises herself to another profession, the one who "come[s] [to the playhouse] for no other Purpose, than to create Acquaintance with as many as seem desirous of it" (41). Fantomina, at this moment, acts like a "suppos'd Prostitute" (42). Fantomina pretends to be a prostitute because she is curious "to know in what Manner these Creatures, [prostitutes,] were address'd" (41). Her curiosity is easily gratified by "practising as much as she had observ'd the Behavriour of" other prostitutes in the playhouse (42).

${ }^{[3]}$ Emily Hodgson Anderson expresses a similar idea by saying that "Beauplaisir has maintained a false sense of control linked to his own ability to dissemble" (Anderson, 2005, 7). Like Anderson and Croskery, Catherine Craft also claims that Fantomina "adopts disguises for the gratification of her own pleasures, not necessarily for the gratification of Beauplaisir's" (Craft, 1991, 830). Although the three critics read Haywood's Fantomina from different characters' perspectives, they all disclose how the plot of this novel is contrary to that of a conventional libertine story, as Beauplaisir loses his dominant status to Fantomina. While agreeing with their arguments, I want to further contend that Beauplair's loss of power is significant in the way of revealing another possible definition of the word "disability," a point which I will spell out in this section.

[4] William Hay (1695-1755) was a hunch-backed Whig politician. His Deformity: An Essay is generally considered to be the first autobiography written by a deformed person.

${ }^{[5]}$ In Loving Dr. Johnson, Helen Deutsch delineates Johnson as "the clubbable authority at the center of public masculine feeling and the tortured soul at the limit of private feminine sympathy" (Deutsch, 2005, 4). Deutsch's portrayal of Johnson's double identity illustrates how Johnson lives with his disabilities without losing his dominance in the social life. In other words, Johnson's contemporaries did not downplay Johnson's influence in the literary circle simply because of his physical impairment.

${ }^{[6]}$ For example, Turner claims that "disability, or 'defect,' was subsumed into broader discourses of physical anomaly such as 'deformity' or 'monstrosity" (Turner, 2012, 26). He goes on to elaborate differences between "deformity" and "monstrosity" by arguing that deformity "was defined as a 'spoiling' of the body's form or disfigurement," whereas monstrous bodies 'typically included those which were constituted of an 'excess' of matter - such as conjoined twins, giants, or people with extra fingers or toes - or 'deficit,' such as those with missing limbs, hands, and feet, or dwarfs" (Turner, 2012, 26, 27).

[7] The Test Acts were in force in 1673 and the main purpose of these penal laws was served as a religious test for the public office. The principle was that only people whose religious attitudes conformed to those of the Church of England would be allowed to take public employment. The Test was then repealed at a later time and the act to repeal The Test Acts was called The Sacramental Test. In his article, Swift actually supports The Test Acts even though he understands how such acts may result in dissenters' disabled condition. 
${ }^{[8]}$ When preparing to meet Beauplaisir, Incognita "dress'd herself in as magnificent a Manner, as if she were to be that Night at a Ball at Court, endeavouring to repair the want of those Beauties which the Vizard should conceal, by setting forth the others with the greatest Care and Exactness" (65). In other words, Incognita wears a mask and by that her face remains covered throughout the whole meeting with Beauplaisir.

\section{References}

Anderson, E. (2005). “Performing Passion in Eliza Haywood's Fantomina and Miss Betsy Thoughtless,” The Eighteenth Century. 46(1), 1-15.

Craft, C. (1991) 'Reworking Male Models: Aphra Behn's 'Fair Vow-Breaker,' Eliza Haywood's 'Fantomina,' and Charlotte Lennox’s 'Female Quixote,” The Modern Language Review. 86(4), 821-838.

Croskery, M. (2000). "Masquing Desire: The Politics of Passion in Eliza Haywood's Fantomina.” The Passionate Fictions of Eliza Haywood: Essays on Her Life and Work. K. Saxton and R. Bocchicchio (eds). Kentucky: Univ. Press of Kentucky, 69-94.

Davis, L. (2000). "Dr. Johnson, Amelia, and the Discourse of Disability in the Eighteenth Century." "Defects": Engendering the Modern Body. Ann Arbor: The Univ. of Michigan Press, 54-74.

---,. (1995). Enforcing Normalcy: Disability, Deafness, and the Body. New York: Verso.

Deutsch, H. (2005). Loving Dr. Johnson. Chicago: Univ. of Chicago Press.

Hay, W. (1754). Deformity: An Essay. London: Printed by R. and J. Dodsley, http://galent.galegroup.com/servlet/ECCO, accessed 1oth April 2021.

Haywood, E. (2004). Fantomina and Other Works, ed. By A. Pettit and M. C. Croskery. New York: Broadview Press.

Johnson, S. (1773) A Dictionary of the English Language. London: Printed for W. Strahan, http://galent.galegroup.com/servlet/ECCO, accessed 1oth April 2021.

Jones, R. (2000). “Obedient Faces: The Virtue of Deformity in Sarah Scott's Fiction.” "Defects”: Engendering the Modern Body. Ann Arbor: The Univ. of Michigan Press, 280-302.

Mounsey, C. (2014). Ed. The Idea of Disability in the Eighteenth Century. Lewisburg: Bucknell Univ. Press.

Pender, S. (2000) "In the Bodyshop: Human Exhibition in Early Modern England.” "Defects": Engendering the Modern Body. Ann Arbor: The Univ. of Michigan Press, 95-126.

Potter, T. (2003) “The Language of Feminised Sexuality: Gendered Voice in Eliza Haywood's Love in Excess and Fantomina," Women's Writing. 10(1), 169-86.

Swift, J. (1741-46). “The Advantage Proposed by Repealing the Sacramental Test, Impartially Considered," Volume IV of the Author's Works, Containing, A Collection of Tracts, Relating to Ireland; Among Which are, The Drapier's Letters to the People of Ireland, against Receiving Wood's Half-Pence: Also, Two Original Drapier's Letters. Dublin: Printed by George Faulkner, 338-349.

http://galent.galegroup.com/servlet/ECCO accessed 1oth April 2021.

Thompson, H. (2002). "Plotting Materialism: W. Charleton's The Ephesian Marton, E. Haywood's Fantomina and Feminine Consistency," Eighteenth-Century Studies. 35(2), 195-214.

Turner, D. (2012). Disability in Eighteenth-Century England: Imagining Physical Impairment. New York: Routledge. 